\title{
Experimental on the protective performance of column bridge pier anti-scouring device
}

\author{
Zhejiang Chen ${ }^{1}$, Liang Liu ${ }^{2}$, Yonglin $\mathrm{Hu}^{3}$, Nan Ye ${ }^{4}$, Xiaoli Shen ${ }^{5}$, and Yan Wang ${ }^{5 *}$ \\ ${ }^{1}$ Jinhua City Transportation Investment Group Co., Ltd, 321015 Jinhua, Zhejiang, China \\ ${ }^{2}$ Dongyang highway and transportation management center, 322100 Dongyang, Zhejiang, China \\ ${ }^{3}$ Jindong District Highway and transportation management center, 321015 Jinhua, Zhejiang, China \\ ${ }^{4}$ Construction company of CCCC First Engineering Group Co., Ltd, 100020 Chaoyang, Beijing, China \\ ${ }^{5}$ Zhejiang Sci-Tech University, 310000 Hangzhou, Zhejiang, China
}

\begin{abstract}
Because of the problem of local scour caused by the change of the flow structure caused by the water-resistance of the column bridge pier, the theoretical analysis, and indoor water tank test were used to study the effect of installing a new anti-scouring device in front of the bridge pier on the local scour reduction effect; the influence of the main design parameters such as the height of the protective device, the angle of the protective device and the distance from the protective device to the bridge pier on the local scour of the bridge pier was selected, and the optimal parameter design combination was selected. The test results show that: under the same water flow conditions, the maximum scour depth reduction rate of the measuring point under the protection of the protective device is $48.4 \%$ to $74.2 \%$ compared with the unprotected scour; the reduction rate of the bridge pier is relative to the relative height of the device and the device equivalent. The angle and the distance between the device and the bridge pier are related, and the shock reduction rate decreases with the increase of the flow intensity. In the test range, the ratio of the device height to the water depth is $2 / 3$, the device angle is $60^{\circ}$, and the distance from the bridge pier is 3 . When the diameter of the pier is doubled, the effect of reducing the impact on the pier is the best.
\end{abstract}

\section{Introduction}

Local scour of bridge pier refers to the scour caused by strong eddy current around the pier due to the obstruction of the pier. When the local scour occurs on the pier, the nearby sediment will move with the flow, causing damage to the bridge pier. According to statistics, half of the bridge damage accidents are caused by water erosion, and thus flood scouring has become one of the main threats to the safe operation of bridges. Therefore, the exploration of the scour development process, the water flow structure around the pier abutment, and the calculation of the maximum scouring depth around the pier abutment ${ }^{[1-2]}$ has important guiding significance for engineering design, safe operation of bridges, and research on local scour protection measures ${ }^{[3-5]}$. Pier scour depth is usually calculated according to the superposition of general scour and local scour, common local scour protection measures are mainly protecting local scour around the pier, which is called local scour protection ${ }^{[6]}$. Currently, since partial erosion protection measures for bridge piers are a more effective way to deal with erosion problems, domestic and foreign scholars, such as Yang Shaopeng et al. ${ }^{[7]}$, Liang Fayun et al. ${ }^{[8]}$, Lagasse et al..$^{9]}$, Barkdoll et al. ${ }^{[10]}$, have conducted theoretical research on pier foundation scour, while also doing a lot of research on protection measures for local scour. According to different protection mechanisms, Chiew divides the traditional local anti-scouring measures into active protection measures and passive protection measures ${ }^{[11]}$. Active protection measures mainly include horizontal retainer protection, submerged sill protection, pier slit protection, sacrificial pile protection ${ }^{[12]}$, passive protection measures mainly include riprap protection, expanded foundation protection, concrete bag protection, partial riprap grouting protection ${ }^{[13]}$. However, traditional protective measures have many limitations such as poor stability, easy failure of the protective effect, and easy destruction. Because of this, this article introduces a new type of column bridge pier protection device, through theoretical analysis and water tank test, placed the device in front of the bridge pier, explored its effect on the local scour of the bridge pier. The influence of the height, angle and the distance from the pier on the scour is further analyzed, and the optimal design combination of the protective device is studied.

\footnotetext{
* Corresponding author: an_wangyan@126.com
} 


\section{Theoretical research and protection mechanism of protective device}

\subsection{Protective device and anti-scouring mechanism}

Figure 1 (a) is a schematic diagram of the upstream and downstream water flow changes under the protection of a protective device. Assuming that the water flow is considered as a one-dimensional flow, set the upstream flow rate as $Q$, the water depth without the protection device is $h_{2}$, the water flow velocity is $V_{2}$, and the Froude number is $F_{r}$, The dotted line in the schematic diagram of the surrounding flow is assumed to be the area affected by the protection device, The force of the protection device on the water flow is $F_{f}$, which will form a certain range of upstream water surges, the water surface height increment is $\triangle h$, and the upstream water depth is $h_{1}\left(h_{1}=h_{2}+\triangle h\right)$. Take the upstream section 1 and the downstream section 2 of the protective device as the isolation body analysis, and study the flow change law when the protective device exists, as shown in Figure 2 (b).
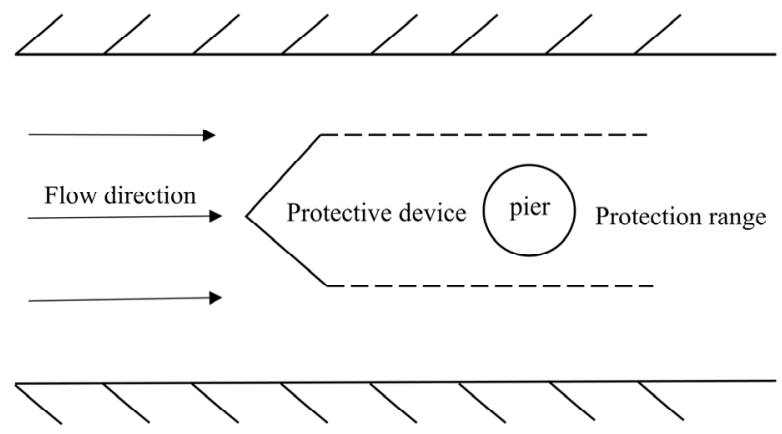

(a) Plan of flow direction

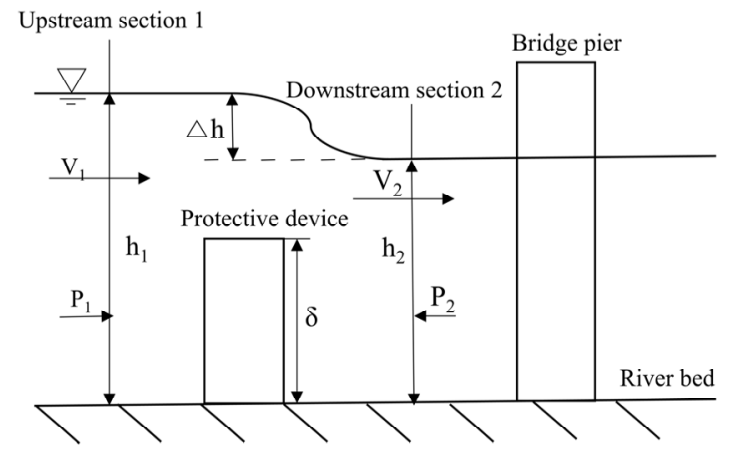

(b) elevation of water surface change

Fig. 1. Flow variation of upstream and downstream of protective device

Suppose $P_{1}$ is the water flow pressure of upstream section $1, V_{1}$ is the water flow velocity of upstream section 1 , and $\mathrm{P}_{2}$ is the water flow pressure of downstream section 2. According to fluid dynamics analysis, section 1 and section 2 satisfy the momentum equation of fluid movement: $v_{0}=\left(\frac{h}{d}\right)^{0.14}\left(29 d+0.000000605 \frac{10+h}{d^{0.72}}\right)^{0.5}$

Where $\rho$ is the density of water, and the density of water at room temperature is $1000 \mathrm{~kg} / \mathrm{m}^{3}$.

Assuming that both points $P_{1}$ and $P_{2}$ conform to the law of hydrostatic pressure distribution under gravity, then:

$$
\begin{gathered}
P_{1}=\frac{1}{2} \rho g\left(h_{2}+\Delta h\right)^{2} \\
P_{2}=\frac{1}{2} \rho g h_{2}{ }^{2}
\end{gathered}
$$

Where, $g$ is the acceleration of gravity, taking $9.81 \mathrm{~m} / \mathrm{s}^{-2}$, is the density of water. Let $F_{f}$ be the flow resistance, that is:

$$
F_{f}=\frac{1}{2} C_{D} \delta \rho v_{1}^{2}
$$

Where $C_{D}$ is the flow resistance coefficient.

According to the continuity equation, the relationship between the flow velocity $V_{1}$ and the flow velocity $V_{2}$ satisfies:

$$
V_{1}=V_{2} h_{0} /\left(h_{2}+\Delta h\right)=Q /\left(h_{2}+\Delta h\right)
$$

The Froude numbers $F_{r 1}$ and $F_{r 2}$ of section 1 and section 2 are expressed as follows:

$$
\begin{gathered}
F_{r 1}=V_{1}^{2} / g h_{0} \\
F_{r 2}=V_{2}^{2} / g h_{0}
\end{gathered}
$$

Put formula (2)-formula (5) into formula (1), then put formula (6)-formula (7) into formula (1), and finally get formula (8):

$$
C_{d} \delta F_{r_{1}^{2}}=2 \Delta h\left[1-\frac{F_{r_{2}^{2}} h_{2}^{2}}{\left(h_{0}+\Delta h\right)^{2}}\right]
$$

According to the analysis of formula (8), it is known that as the height of the protective device $\delta$ increases, $\Delta h$ will inevitably increase. At this time, the upstream water flow intensity of $F_{r l}$ will decrease. According to the basic theory of river sediment kinematics, the weakening of the flow intensity of the water will reduce the sediment transport capacity of the water, thereby achieving the purpose of weakening the local scour near the bridge pier. However, as shown in Figure 2 (b), if the height $\delta$ of the protective device increases, the partial water surface gradient downstream will increase, which may cause downstream scouring. Therefore, the height of the protective device needs to be set reasonably.

\section{Test design}

\subsection{Model design}

To facilitate the observation of the test phenomenon, this test was carried out in a glass water tank. To ensure the stability of the test water flow, in addition to setting a 
rectifying grid at the water inlet, a certain distance between the water inlet and the water outlet of the tank should be left at the transition section, and at the same time, a grit chamber should be set downstream of the test section. The radius of the model bridge pier in this experiment is $0.02 \mathrm{~m}$, so the theoretically calculated minimum flume width is $0.4 \mathrm{~m}$. According to factors such as the laboratory site and the water supply capacity of the water circulation system, the test tank is finally determined: size length $\times$ width $\times$ height $=3 m \times 0.8 m \times 0.5 m$, rectangular linear open sink, equipped with an independent water supply and backwater systems, As shown in Figure 2.

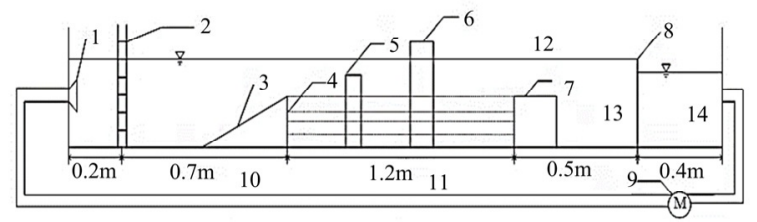

(a)Elevation layout: 1. Outlet; 2. Rectifying grid; 3. Anterior sill; 4. Model sand; 5. Protective device; 6. Pier; 7. Back sill; 8 . Overflow board; 9. Pump; 10. Inlet transition section; 11. Test section; 12. Exit transition section; 13. Grit chamber; 14. Backwater area

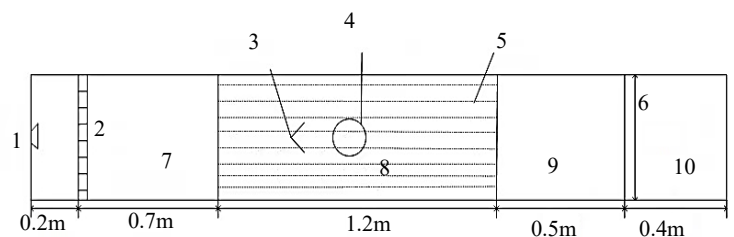

(b)Layout plan: 1. Intake; 2. Rectifying; 3. Protective device; 4. Pier; 5. Model sand; 6. Tailgate; 7. Inlet transition section; 8. Test section; 9. Exit transition section; 10. Backwater area

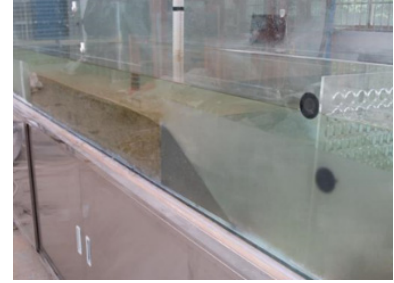

(c) Elevation of flume

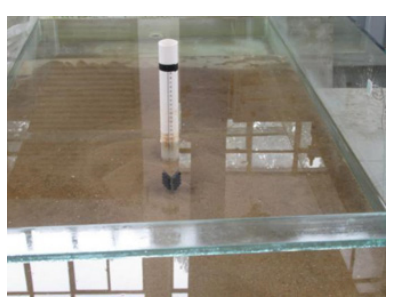

(d) Flume test section
Fig. 2. Test layout

\subsection{Test materials}

After comparison, the simulated river bed uses sand with an average particle size of $\mathrm{d}=0.7 \mathrm{~mm}$ as the model sand. The sand has a saturated density of $2.188 \mathrm{~g} / \mathrm{cm}^{3}$ and a dry density of $1.489 \mathrm{~g} / \mathrm{cm}^{3}$. The model sand thickness of the test section is $15 \mathrm{~cm}$, and the water depth is $10 \mathrm{~cm}$. In our country, the scour calculation is calculated using the sediment starting velocity formula (9) derived by Zhang Ruijin, whose coefficients and indices are based on the data compiled by Dou Guoren.

$$
v_{0}=\left(\frac{h}{d}\right)^{0.14}\left(29 d+0.000000605 \frac{10+h}{d^{0.72}}\right)^{0.5}
$$

Where $v_{0}$ is the starting flow rate $(\mathrm{m} / \mathrm{s}) ; h$ is the water depth $(m) ; d$ is the particle size $(m)$

To ensure that the test is flushed by clean water, the test flow rate is determined to be $0.16 \mathrm{~m} / \mathrm{s}$ according to the formula calculation, which can not only meet the requirements of the starting flow rate of sediment in front of the baffle but also ensure that the river bed sediment will not generally start.

In this experiment, the model pier is made of PVC pipe with a diameter of $4 \mathrm{~cm}$ and a height of $40 \mathrm{~cm}$. The protective device is made of an iron sheet folded in half along the shorter side with a thickness of $0.03 \mathrm{~cm}$. The lengths of the longer side of the iron sheet are $17.5 \mathrm{~cm}$, $20 \mathrm{~cm}, 22.5 \mathrm{~cm}, 25 \mathrm{~cm}$, namely $1 / 4 h, 1 / 2 h, 3 / 4 h, 4 / 4 h$. The shorter side of the iron sheet is $8 \mathrm{~cm}$, namely twice the diameter of the model pier.

\subsection{Test program}

In this test, the combined design is mainly based on the protection device's height, angle, and distance between the protection device and the bridge pier. By measuring the change of scour depth at the measuring point of the bridge pier and comparing and analyzing the scour depth without protection, the optimal parameter design of the protection device is obtained. The test parameters are shown in Table 1. The experimental design conditions were combined according to the parameters in the table. A total of 49 groups of tests were designed, including unprotected control tests.

Table 1. Test parameters.

\begin{tabular}{|c|c|c|c|}
\hline \multirow{2}{*}{ Level } & \multicolumn{3}{|c|}{ Variable } \\
\cline { 2 - 4 } & $\begin{array}{c}\text { Baffle } \\
\text { height/cm }\end{array}$ & Baffle angle & $\begin{array}{c}\text { Baffle } \\
\text { distance/cm }\end{array}$ \\
\hline 1 & $1 / 4 \mathrm{~h}$ & $30^{\circ}$ & $2.5 \mathrm{D}$ \\
\hline 2 & $1 / 2 \mathrm{~h}$ & $45^{\circ}$ & $3.5 \mathrm{D}$ \\
\hline 3 & $3 / 4 \mathrm{~h}$ & $60^{\circ}$ & $4.0 \mathrm{D}$ \\
\hline 4 & $4 / 4 \mathrm{~h}$ & $75^{\circ}$ & $/$ \\
\hline
\end{tabular}

Note: the height of baffle refers to the height of baffle exposed to the riverbed, excluding the height in the riverbed; baffle distance refers to the distance from baffle tip to pier center; $h$ is water depth; $\mathrm{D}$ is pier diameter.

Main test steps: (1)Embed the bridge pier model in the middle of the test section, spread the sand thickness of the model to $15 \mathrm{~cm}$, place the flow meter in front of the bridge pier, out of the scope of the water surge, and smooth the surface of the river bed. Slowly release the water before the start of the test, and stop the release after the riverbed has passed. After the sediment is fully soaked and settled, continue to release the water to reach the required water level of the test; (2) After the start of the test, the water supply gradually increased and the flow rate gradually increased. According to the observations of multiple pre-test results, it was determined that the erosion reached a relative 
equilibrium after about 8 hours of test erosion. To avoid the interference of the flow rate measurement on the erosion test, the initial flow rate measurement was completed Then take out the flow meter; (3) When the scour time reaches the specified time, shut off the water pump and empty the water tank, take photos and record the riverbed topography around the protection device and the bridge pier, and measure the scour at the bottom of the bridge pier. The layout of the scour points is shown in Figure 3.

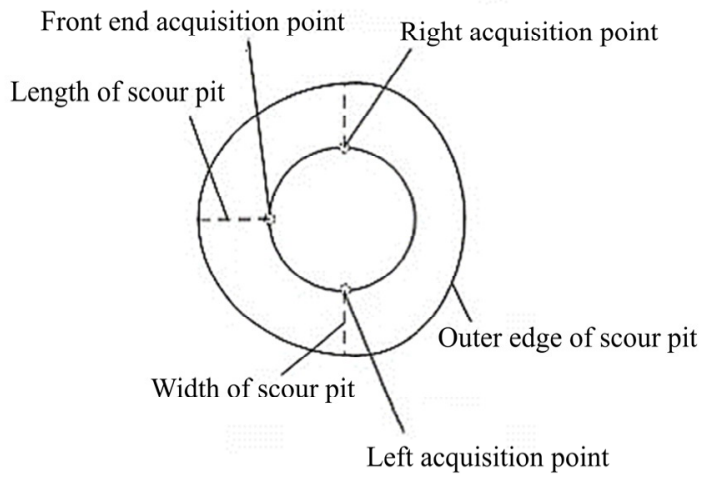

Fig. 3. Layout of measuring points for scouring depth of the pier.

\section{Results and analysis}

After the scour process reaches a relative balance, use a high-precision triangular ruler and model pier scale stickers to measure the final scour depth of the collection points at the front, left, and right sides of the pier. The shape of the scour pit and the development process of the scour are shown in Figure 4. The influence trend of devices with different parameter combinations on the scour depth of measuring points around the pier is shown in Figure 5.

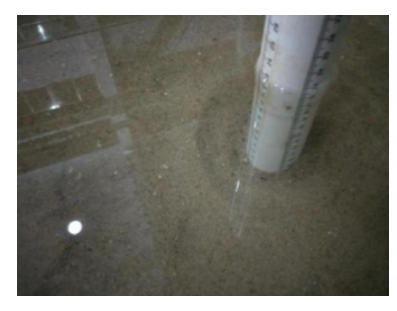

(a) Unprotected scour pit

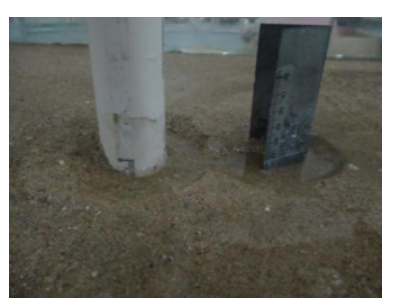

(d) Protected scour pit

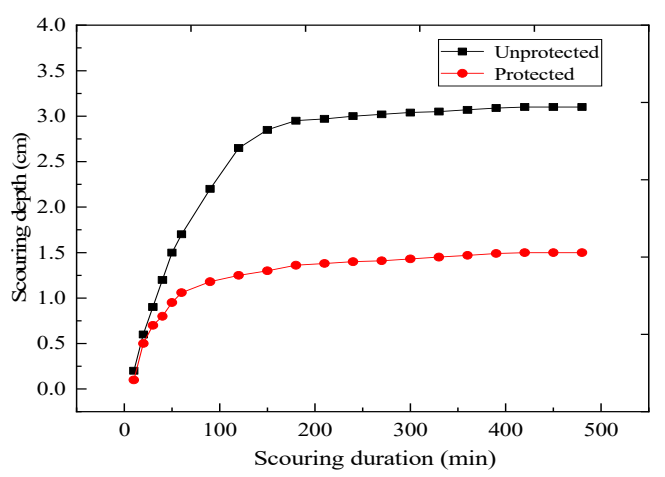

(c) Contrast curve of scouring development process

Fig .4. Scour pit and development curve of scouring.
The test is divided into protection test and nonprotection test. As shown in Figure 4, the whole test process can be divided into three stages, regardless of whether there is protection or not: the initial scour period, scour starts from both sides of the pier head of the pier, and develops from both sides to the pier head until it connects to form a scour pit. The scour depth develops relatively rapidly, and at the same time, a siltation area is formed on the back water side of the pier under the action of eddy current transportation. During the scour development period, the scour depth continues to increase at this stage, the sediment in the scour pitfalls randomly, and the scope of the scour pit continues to expand. The scour development at this stage is very slow, the scour depth tends to a certain depth to stabilize, and the scope of the scour pit is no longer expanded; the scour development in the early stage of the whole process is rapid, and the development of the scour in the middle and late stages is slow. The effect is greater, and the strong flow of the water flow leads to violent scouring. As the scour process progresses, the water passing area increases and the squeezing effect decreases, and the scour development gradually stabilizes. As shown in Figure 6:

(1) Without protection, the maximum scouring depth at the measuring point of the bridge pier can reach $3.1 \mathrm{~cm}$. When protective measures are taken, the height and angle of the protection device and the distance between the device and the pier are all against the local scouring It isinfluential. According to different parameter combinations, the reduction rate of the deepest measuring point of the scour depth around the pier is $48.4 \%-74.2 \%$. It can be seen that the protective effect of the protective device on the local scour of the bridge pier is more significant;

(2) It can be seen from Figures (a) (d) that when the angle and distance are fixed parameters and the height of the device is used as a variable, the effect of the height of the device on the scouring is studied. When the height increases from $1 / 4 \mathrm{~h}$ to $3 /$ At $4 \mathrm{~h}$, the scour depth of the bridge pier measurement point showed a downward trend. When the height continued to increase from $3 / 4 \mathrm{~h}$ to $4 / 4 \mathrm{~h}$, the scour depth increased. When the height was $3 / 4 \mathrm{~h}$, the scour depth was the smallest; Strengthening the dissipative effect of the device on the potential energy of water flow, and weakening the flow intensity according to the theory of sand dynamic movement, can weaken the scour effect of the water flow on the riverbed of the bridge pier behind the device, and protect the foundation of the bridge pier; and when the height of the device is too high, It will cause the water surface of the downstream and the upstream water surface to drop too much, causing downstream scouring, so the height of the device needs to be controlled reasonably;

(3) It can be seen from Figures (e) $\sim$ (g) that with height and distance as fixed parameters, and installation angle as a variable, as the installation angle changes, the local scour depth of the bridge pier is different. When the angle changes from $30^{\circ}$ When the angle is increased to $60^{\circ}$, the scouring depth shows a downward trend. When the angle is increased from $60^{\circ}$ to $75^{\circ}$, the scouring depth shows an upward trend, and the scouring depth is the 
smallest when the angle is $60^{\circ}$; the included angle is appropriately increased, and the device shields the rear area And the scope of influence has increased. The diversion, diversion, and dissipation effects of the water flow through the device have greatly weakened the flow strength when flowing through the bridge pier, and the erosion effect on the bridge pier river bed has been significantly reduced; when the device angle is too large, It will also cause the diversion effect of the device to be reduced, and at the same time cause the upstream and downstream water surface drop to be too large, which is not conducive to local erosion;

(4) It can be seen from Figure (i) Figure (k) that when the angle and height remain unchanged, and the distance from the pier is used as a variable when the distance increases from $2.5 \mathrm{D}$ to $4.0 \mathrm{D}$, the erosion depth changes first to decrease Later, when the distance to the bridge pier is $3.5 \mathrm{D}$, the scour depth of the measuring point reaches the minimum; the protective device is a "V"-shaped plate-shaped impervious structure, which has certain obstruction and compression to the water flow. When the device is close to the pier, the device The surrounding water current and the water current around the bridge piers form a superimposed effect, which is not conducive to local scour; when the device is far away from the bridge pier, and the bridge pier is at the end of the protective device's influence area, the shielding and diversion effects of the device attenuate and scour The protection effect is poor, so the scouring depth decreases first and then increases as the distance changes;

(5) Analyzing the data in Figure 6, when the device angle is $60^{\circ}$, the distance from the bridge pier is $3.5 \mathrm{D}$, and the height is $3 / 4 \mathrm{~h}$ water depth, the protective effect of the bridge pier is the best. The point scours depth is $0.6 \mathrm{~cm}, 0.7 \mathrm{~cm}, 0.8 \mathrm{~cm}$, and the maximum attenuation rate is $74.2 \%$.

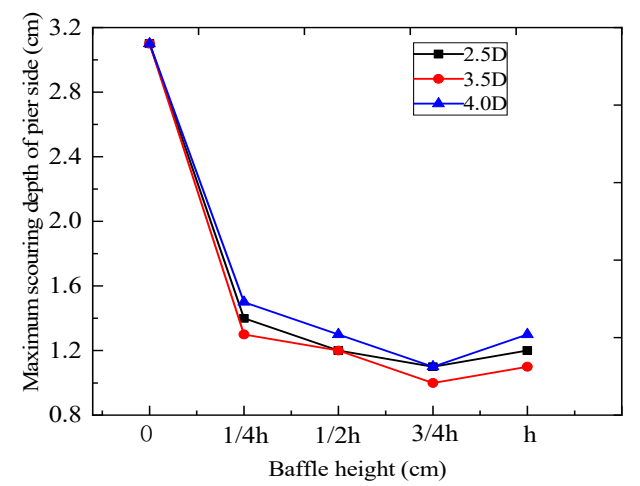

(a) Maximum scour depth at $30^{\circ}$ angle

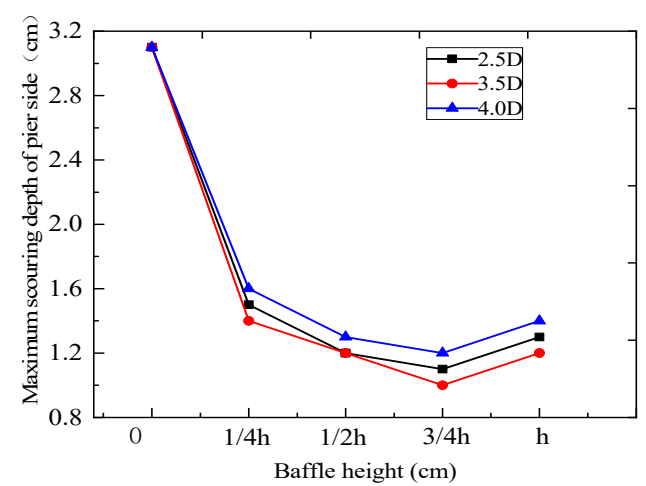

(b) Maximum scour depth at $45^{\circ}$ angle

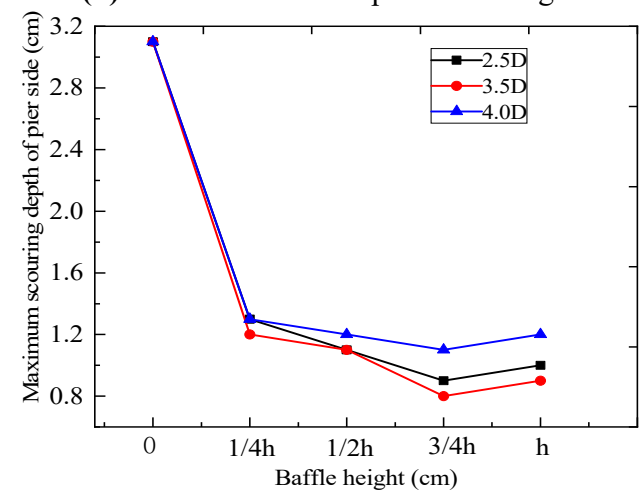

(c) Maximum scour depth at $60^{\circ}$ angle

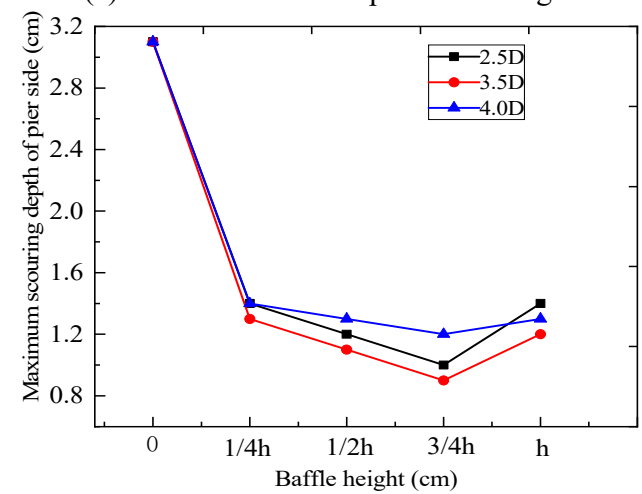

(d) Maximum scour depth at $75^{\circ}$ angle

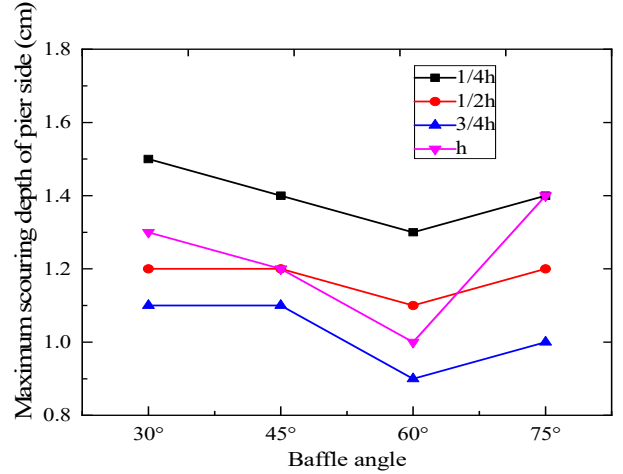

(e) Maximum scour depth at 2.5D 


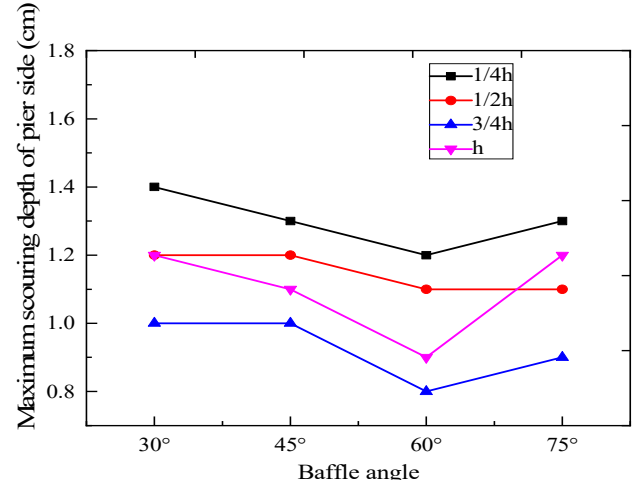

(f) Maximum scour depth at $3.5 \mathrm{D}$

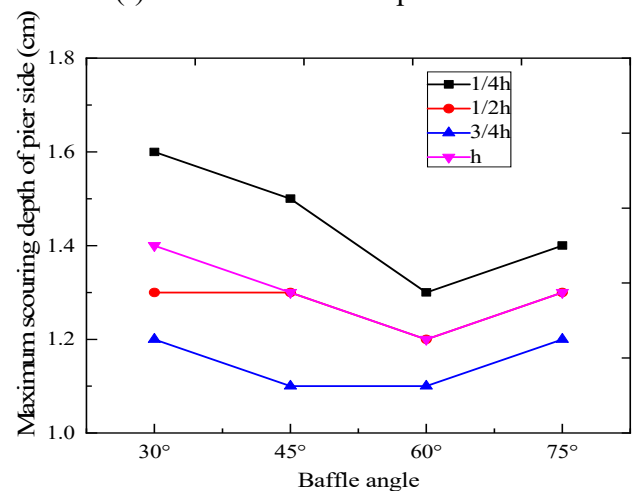

(g) Maximum scour depth at4D

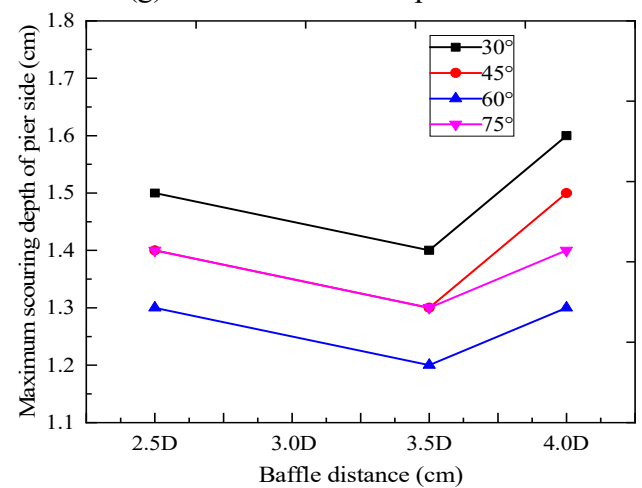

(h) Maximum scour depth at $1 / 4 \mathrm{~h}$ height

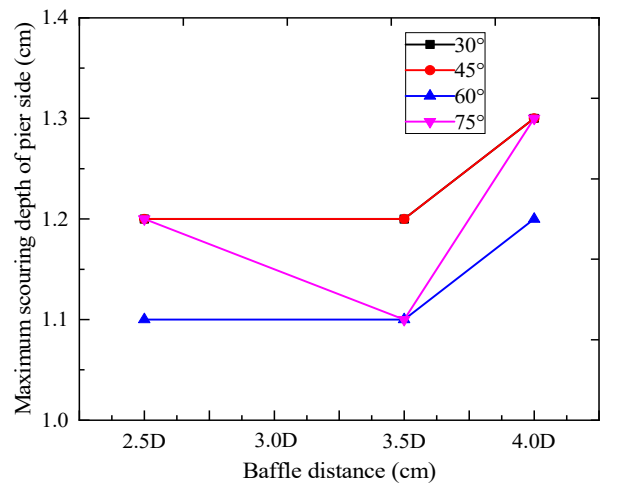

(i) Maximum scour depth at $2 / 4 \mathrm{~h}$ height

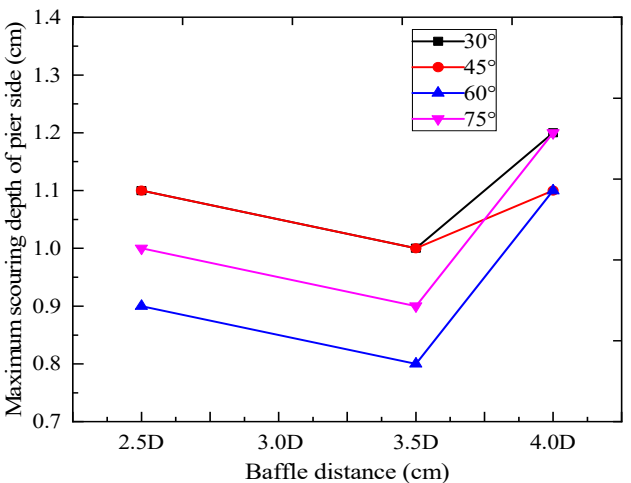

(j) Maximum scour depth at $3 / 4 \mathrm{~h}$ height

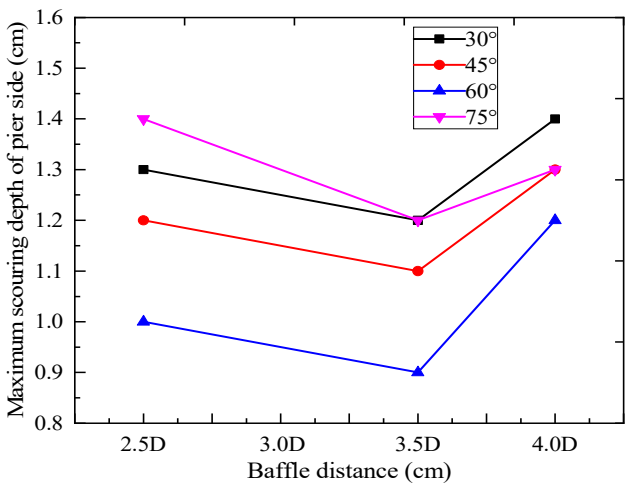

(k) Maximum scour depth at $4 / 4 \mathrm{~h}$ height

Fig .5.Scour pit and development curve of scouring.

\section{Conclusion}

Many influencing factors cause the local scour phenomenon of bridge piers, and the mechanism of pier scour is complicated. At present, the understanding of the local scour of bridge piers and the research of protective measures cannot well solve the needs of engineering problems. The column bridge pier scours prevention device proposed in this paper is a new method superior to traditional local scour protection measures. It is not only theoretically feasible but also has good protection against bridge piers and has a certain degree of protection against local scour. The main conclusions of the project value are as follows:

(1) The local scour process can be divided into three stages: the initial scour stage, the slow development stage of the scour, and the balanced scour stage. According to the experiment, during the initial scour stage, the scour depth and scour pit depth develop rapidly, and the scour depth can reach about $70 \%$ of the final scour depth; in the slow development stage, the scour intensity decreases significantly, and the scour depth and scour pit develop slowly; In the balanced scour stage, the scour depth reaches a certain value and remains unchanged, and there is no obvious development of scour pits.

(2) The protection device shortens the time for the scour of the pier to reach the balanced state, which also makes the scour process reach stability quickly. This is due to the diversion and separation of the water flow and the energy dissipation of the flow by the protective device so that the local scour of the bridge pier is carried 
out under the condition of a lower flow field. Compared with the unprotected state, its scour will reach a lower dynamic balance faster.

(3) The height, angle, and distance from the bridge pier will all have an impact on the protective effect of local scour. Compared with the unprotected test, under the protection of the device, the reduction rate of the scour depth of the deepest measuring point around the bridge pier can reach $48.4 \% \sim 74.2 \%$, it can be seen that the protective effect of the device is obvious, and it is feasible to adopt this new protective measure to protect the local scour of the bridge pier. According to the test data, when the design parameters of the protection device are "V" Angle $60^{\circ}$, the height of the device is $3 / 4 \mathrm{~h}$ ( $\mathrm{h}$ is the river depth) and the distance from the center of the bridge pier is 3.5D ( $\mathrm{D}$ is the diameter of the bridge pier), it is the best design combination and the protection effect is the best.

\section{Acknowledgments}

This research was funded by the Science and technology projects of Zhejiang Provincial Department of transportation in 2019 (2019022).

\section{References}

1. Liang Fayun, Peng Jun, Wang Chen. Experimental study on scour characteristics of pile group foundation in river bed with overlying coarse sand layer[J]. Journal of Tongji University (Natural Science Edition), 2017, (7): 42-48.

2. Me MK, Me HMA. Bridge Pier Scour Prediction By Gene Expression Programming[J]. Proceedings of the Institution of Civil Engineers, 2012, 165(9): 481.

3. Lagasse PF, Clopper P, Zevenbergen L, et al. Nchrp Report 593: Countermeasures to Protect Bridge Piers From Scour[J]. Transportation Research Board of the National Academies, Washington, Dc, 2007.

4. Duan L, Liao C, Jeng D, et al. 2d Numerical Study of Wave and Current-induced Oscillatory Non- cohesive Soil Liquefaction Around a Partially Buried Pipeline in a Trench[J]. Ocean Engineering, 2017, 135: 39-51.

5. Zhang Q, Draper S, Cheng L, et al. Time Scale of Local Scour Around Pipelines in Current, Waves, and Combined Waves and Current $[\mathrm{J}]$. Journal of Hydraulic Engineering, 2016, 143(4): 4016093.

6. Fang Shilong. Experimental study on the influence of local scour pits on flow field characteristics near bridge piers[J]. Water Transportation Engineering, (11): 143-152.

7. Huang Donghai. Calculation of local scour depth around renovating buildings[J]. Water Transport Engineering, (11): 31-34, 44.

8. Cheng Lanyan, Mou Xianyou, Wen Heng, et al. Local scour protection test of ring-wing bridge piers $[\mathrm{J}]$. Progress in Water Resources and Hydropower Science and Technology, 2012, 32(3): 14-18.

9. Qi Meilan, Yang Yilin, Xi Yanrong. Research on the effect and mechanism of bottom sill on alleviating the erosion of bridge piers in sand mining riverbed[J]. China Railway Science, 2017, 38(4): 35-41.

10. Yang Shaopeng, Shi Bing. Experimental study on scour protection of bridge piers by artificial grass $[\mathrm{C}]$ //data collection of Shandong Institute of Oceanography, limnology, 2017, 2017.

11. Liang Fayun, Wang Chen. Experimental study on protection method of sacrificial pile for local scour of pier foundation [C]// 17th China Ocean (Shore) Engineering Symposium, 2015.

12. Barkdoll BD, Ettema R, Melville BW. Countermeasures to Protect Bridge Abutments From Scour[M]. [S.1.]: Transportation Research Board, 2007.

13. Chiew Y. Scour Protection at Bridge Piers[J]. Journal of Hydraulic Engineering, 1992, 118(9): 1260-1269. 